\title{
Sensitive Method for Testing Peanut Seed Lots for Peanut stripe and Peanut mottle viruses by Immunocapture-Reverse Transcription-Polymerase Chain Reaction
}

\author{
A. G. Gillaspie, Jr., R. N. Pittman, and D. L. Pinnow, United States Department of Agriculture-Agricultural Re- \\ search Service, Plant Genetic Resources Conservation Unit, Griffin, GA 30223-1797; and B. G. Cassidy, Samuel \\ Roberts Noble Foundation, Inc., Ardmore, OK 73402
}

\begin{abstract}
Gillaspie, A. G., Jr., Pittman, R. N., Pinnow, D. L., and Cassidy, B. G. 2000. Sensitive method for testing peanut seed lots for Peanut stripe and Peanut mottle viruses by immunocapture-reverse transcription-polymerase chain reaction. Plant Dis. 84:559-561.

An immunocapture-reverse transcription-polymerase chain reaction (IC-RT-PCR) method was developed for testing peanut (Arachis hypogaea) seed lots for infection by Peanut stripe virus (PStV) and Peanut mottle virus (PeMV). A small slice was removed from each seed distal to the radicle of a random 100-seed sample, the slices were extracted in buffer and centrifuged, and a portion of the supernatant was incubated in a tube that had been coated with antiserum to either PStV or PeMV. Following immunocapture of the virus, the tube was washed, the RT-PCR mix (with primers designed from conserved sequences within the capsid region of each virus) was placed in the same tubes, and the test completed. Results obtained on 15 previously untested seed lots from the collection indicated good correlation between virus detected by the IC-RTPCR method and virus detected from the same seed lots by enzyme-linked immunosorbent assay (ELISA). The IC-RT-PCR method detected three lots infected with PeMV and none with PStV from 106 seed lots grown in Ecuador (results confirmed by ELISA). The IC-RT-PCR method is more sensitive than ELISA (currently used on samples consisting of five seeds), is useful for testing large numbers of seed lots of peanut germ plasm, and could be adapted to test other plants and detect other viruses.
\end{abstract}

Peanut stripe virus (PStV) was found in the United States in field-grown peanut plants (Arachis hypogaea L.) in $1982(3,4)$. The virus originated from peanut seed germ plasm from the People's Republic of China and seed transmission was over 5\% in some lots. Yield reductions by PStV in peanuts in Georgia were about $7 \%$ in experimental plots (9). Peanut mottle virus (PeMV) was reported from peanut plants in Georgia in 1961, and the virus was found to be seed transmitted at a rate of $2 \%$ and to reduce yield by about $25 \%$ in experimental plots (8).

The seedborne nature of these and other viruses in peanut is of considerable interest in the international exchange of germ plasm because of the potential economic damage that could result from the introduction of new strains of the viruses into peanut-growing areas. Currently, there is an effort to detect all seedborne viruses in newly introduced peanuts and to eliminate the viruses from the germ plasm before it

Corresponding author: A. G. Gillaspie, Jr.

E-mail: s9gg@ars-grin.gov

Accepted for publication 24 January 2000.

Publication no. D-2000-0313-03R

This article is in the public domain and not copyrightable. It may be freely reprinted with customary crediting of the source. The American Phytopathological Society, 2000. is grown in fields or distributed. Virus detection is currently done by enzymelinked immunosorbent assay (ELISA) using seed or vegetative tissues $(5,13)$. The ELISA is commonly used to detect virus in batches of five seeds, but it can be sensitive enough to detect $1 \mathrm{PSt} V$-infected seed in 30 seeds (14). Once a diseased batch is detected, each seed in the batch must be tested individually to verify virus-free seeds. The numerous seed lots to be tested and the time required to examine each lot have stimulated interest in development of more sensitive, high-throughput methods. Although reverse transcription-polymerase chain reaction (RT-PCR) has been shown to detect PStV in peanut seed (14), it has not been tested on a significant scale. We received 106 peanut seed lots from a growout in Ecuador and had other seed lots that needed to be tested for virus infection. To accommodate screening large numbers of potentially virus-infected seeds in a timely fashion, we developed a high-capacity, sensitive method using immunocapture (IC)-RT-PCR (11).

\section{MATERIALS AND METHODS}

Peanut seed lots tested. Preliminary evaluation of the IC-RT-PCR procedure was conducted on 15 previously untested peanut seed lots from the National Germplasm Collection maintained at Griffin, Georgia. Samples from these lots were tested by double-antibody sandwich
(DAS)-ELISA $(5,13)$ and the results compared to those obtained by IC-RT-PCR on the samples. We then tested 106 seed lots from Ecuador by IC-RT-PCR. Those samples testing positive for one or both viruses, as well as random samples of those testing negative for either virus by IC-RTPCR, were tested by ELISA. Positive controls were developed using virus-infected plant material previously determined by ELISA.

Virus extraction. PStV and PeMV were determined to be present in the cotyledon tissues of infected plants (13). Therefore, virus was extracted from peanut seed cotyledons or from leaf tissue for the development of the RT-PCR procedures: 0.5 $\mathrm{g}$ of tissue was ground in RNA extraction Qiagen lysis buffer containing guanidine isothiocynanate, mixed with sarkosyl, heated at $70^{\circ} \mathrm{C}$, and processed through a Qiagen mini-prep spin column (Qiagen Inc., Chatsworth, CA) to yield a preparation containing total RNA (10).

For IC-RT-PCR, peanut seeds were sampled by a modified nondestructive technique (13). A small slice was removed from each cotyledon distal to the radicle with a razor blade and the slices triturated in extraction buffer $(1,000 \mathrm{ml}$ of PBST $\left[0.137 \mathrm{M} \mathrm{NaCl}, 1 \mathrm{mM} \mathrm{KH} \mathrm{PO}_{4}, 8 \mathrm{mM}\right.$ $\mathrm{Na}_{2} \mathrm{HPO}_{4}, 3 \mathrm{mM} \mathrm{KCl}, 0.05 \%$ Tween-20, 3 $\mathrm{mM} \mathrm{NaN}_{3}$ ] containing $0.01 \mathrm{M} \mathrm{Na}_{2} \mathrm{SO}_{3}, 2 \%$ polyvinylpyrrolidone $\mathrm{MW} 40,000,3 \mathrm{mM}$ $\mathrm{NaN}_{3}, 2 \%$ powdered milk, and $2 \%$ Tween20, pH 7.4). For tests of seed lots, one 100seed sample was selected at random from each seed lot. The sampling method was the same used in previous tests conducted on cowpea (Vigna unguiculata (L.) Walp. subsp. unguiculata) field-grown seed lots in which 20 five-seed samples were chosen at random and combined. Three such 100seed samples from six seed lots were planted in flats and virus infection determined by symptomology and ELISA. The results indicated that samples from a given seed lot were identical or varied by only one positive plant for any of the viruses tested (unpublished results). The seed slices were combined for each seed lot and triturated in $20 \mathrm{ml}$ of extraction buffer in a grinding bag (Agdia Inc., Elkhart, IN), after which the slurry was centrifuged at $14,000 \times g$ for $5 \mathrm{~min}$. Samples of the aqueous portion were then used for testing.

IC-RT-PCR. PCR tubes $(200 \mu \mathrm{l})$ were soaked in $0.1 \mathrm{M} \mathrm{HCl}$ for $15 \mathrm{~min}$, rinsed in 
Table 1. Comparison of by immunocapture-reverse transcription-polymerase chain reaction (IC-RTPCR) and enzyme-linked immunosorbent assay (ELISA) to detect Peanut stripe virus (PStV) and Peanut mottle virus (PeMV)

\begin{tabular}{|c|c|c|c|c|}
\hline \multirow[b]{2}{*}{ Peanut accession ${ }^{a}$} & \multicolumn{2}{|c|}{ PStV } & \multicolumn{2}{|c|}{ PeMV } \\
\hline & IC-RT-PCR & ELISA $^{b}$ & IC-RT-PCR & ELISA $^{b}$ \\
\hline Grif 12578 (Ecuador) & - & 0 & + & 3 \\
\hline Grif 12595 (Ecuador) & - & 0 & + & 4 \\
\hline Grif 13808 (Ecuador) & - & 0 & + & 1 \\
\hline PI 118989 & + & 1 & + & 4 \\
\hline PI 274194 & + & 3 & + & 1 \\
\hline PI 274197 & + & 2 & + & 1 \\
\hline PI 275687 & + & 9 & + & 2 \\
\hline PI 429444 & - & 0 & + & 4 \\
\hline PI 429449 & - & 0 & + & 3 \\
\hline PI 442581 & + & 12 & + & 1 \\
\hline PI 442588 & + & 5 & + & 2 \\
\hline PI 442589 & + & 5 & - & 0 \\
\hline PI 442708 & + & 9 & + & 2 \\
\hline PI 468134 & + & 10 & - & 0 \\
\hline
\end{tabular}

${ }^{\mathrm{a}}$ PI = Plant Introduction numbers. Additional peanut accessions (PI 275688, 275695, 306232, 475976, and 103 Grifs from Ecuador) all tested negative for both viruses by both methods.

b Number of seeds infected of 100 tested.

PBST, soaked in $4 \mathrm{M} \mathrm{NaOH}$ for $15 \mathrm{~min}$, rinsed in PBST, soaked in $95 \%$ ethanol for $15 \mathrm{~min}$, and air dried. This treatment of the tubes is necessary to condition the tubes so that the antibodies will become more firmly attached. They were coated with 50 $\mu \mathrm{l}$ of a 1:500 dilution of either PStV (J. W. Demski, University of Georgia, Griffin) or PeMV (M. S. Hopkins, United States Department of Agriculture-Agricultural Research Service [USDA-ARS], Griffin, GA) whole antiserum in coating buffer $(15 \mathrm{mM}$ $\mathrm{Na}_{2} \mathrm{CO}_{3}, 35 \mathrm{mM} \mathrm{NaHCO}, 3 \mathrm{mM} \mathrm{NaN}$, $\mathrm{pH}$ 9.6) for $3 \mathrm{~h}$ at $37^{\circ} \mathrm{C}$ or overnight at $4^{\circ} \mathrm{C}$. The highest effective dilution of antiserum to use was determined by a titration experiment using a DAS-ELISA procedure to determine binding capacity of the treated tubes. The tubes were washed three times with $200 \mu \mathrm{l}$ of PBST and incubated with $50 \mu \mathrm{l}$ of the seed extract supernatant or a leaf extract (control) for 2 to $3 \mathrm{~h}$ at room temperature or overnight at $4{ }^{\circ} \mathrm{C}$. Each antiserum-seed extract combination was replicated. The tubes were washed again three times with PBST and blotted dry on a tissue. They were placed at $-70^{\circ} \mathrm{C}$ for at least $10 \mathrm{~min}$ and the contents thawed at $94^{\circ} \mathrm{C}$ for $2 \mathrm{~min}$ to disassemble the antibody-bound virus and free the viral RNA from the protein coat. A total of $50 \mu \mathrm{l}$ of RT-PCR mix $(4 \mu \mathrm{l}$ of $5 \times$ first-strand reverse transcription buffer [Life Technologies, Frederick, MD], $2 \mu \mathrm{l}$ of 0.1 M DTT, $2.6 \mu \mathrm{l}$ of $10 \mathrm{mM}$ dNTP, $0.1 \mu \mathrm{l}$ of RNasin RNase inhibitor [Promega Corp., Madison, WI], $0.25 \mu \mathrm{l}$ of SuperScript RNase $\mathrm{H}^{-}$ Reverse Transcriptase [Life Technologies], $3 \mu \mathrm{l}$ of $10 \times$ PCR buffer [Promega Corp.], $4.2 \mu \mathrm{l}$ of $25 \mathrm{mM} \mathrm{MgCl} 2,1 \mu \mathrm{l}$ of reverse primer [primers at $100 \rho \mathrm{M} / \mu \mathrm{l}], 0.5 \mu \mathrm{l}$ of forward primer, $0.2 \mu \mathrm{l}$ of $\mathrm{Taq}$ polymerase [Promega Corp.], and $32.75 \mu \mathrm{l}$ of nucleasefree water) was added to each tube. The tubes were then treated as follows: $37^{\circ} \mathrm{C}$ for $1 \mathrm{~h}, 94^{\circ} \mathrm{C}$ for $2 \mathrm{~min},\left(35\right.$ cycles of $94^{\circ} \mathrm{C}$ for $30 \mathrm{~s}, 50^{\circ} \mathrm{C}$ for $30 \mathrm{~s}$, and $72^{\circ} \mathrm{C}$ for $60 \mathrm{~s}$ ), and $72^{\circ} \mathrm{C}$ for $10 \mathrm{~min}$. The forward PeMV primer sequence $\left(5^{\prime}\right.$ to $\left.3^{\prime}\right)$ was TCA ACG GAA ATT GGA CCA TGA T and the reverse PeMV primer was GTT CCG ACG TTA CCA TCA AGA CCA with an expected product size of $339 \mathrm{bp}$ based on a previously reported sequence (6). The forward PStV primer sequence ( $5^{\prime}$ to $\left.3^{\prime}\right)$ was GGC GAG TAT GAA ATA GAT and the reverse PStV primer was GGT GGT AAA ACC ACA CTG with an expected product size of $611 \mathrm{bp}$ based on a previously reported nucleic acid sequence (2). Following RT-PCR, the products were assessed by electrophoresis in $1.5 \%$ agarose gels in TBE buffer $(89 \mathrm{mM}$ Tris-borate and $2 \mathrm{mM}$ EDTA, pH 8.3) and stained with ethidium bromide.

\section{RESULTS AND DISCUSSION}

Results indicate that the IC-RT-PCR method can reliably detect PStV and PeMV in peanut seed lots. Testing 100seed samples is most efficient when the seed lots have little infection. An effort to further reduce costs and time by multiplexing the primers test for both viruses simultaneously in one tube was not successful (data not shown). Apparently the viruses are so closely related that they share sequence similarities, resulting in an interaction between the two sets of primers to produce cDNA bands of sizes other than those expected.

The IC-RT-PCR procedure was used to detect Plum pox virus in apricot seeds in an epidemiology study (12) and to detect Plum pox virus, Apple stem pitting virus, and Cherry leaf roll virus in other plant tissues $(1,7,15)$. The technique offers improved sensitivity over that of ELISA, but these are the first results with large volumes of seeds. Many other viruses probably can be detected by this method. All that is required is a wide-spectrum antiserum and a set of primers selected to a highly conserved region, such as the primers re- ported here (B. G. Cassidy and R. Dietzgen, unpublished data), so that all variants of each virus may be detected.

Extraction of test samples was much more rapid and less expensive with the ICRT-PCR procedure than with RT-PCR because the former is essentially that used for ELISA. The lipid-containing material in the seed caused some problems, which were overcome by centrifuging the extracts and removing only the aqueous portion with a pipette. The RNA prepared by the Qiagen method is adequate, but the procedure is expensive and time consuming. The rapid virus extraction and immunocapture of virus from the samples facilitates the handling of larger numbers of samples.

Tests of the sensitivity of the IC-RTPCR method indicated that 1 infected seed with either virus in 100 seeds could be reliably detected (data not shown). Therefore, 100-seed samples were tested, which allowed larger numbers of seed lots to be processed more rapidly than could be done easily by ELISA (even at 30 seeds/lot). The results of ELISA and IC-RT-PCR for the 15 peanut seed lots from the germ plasm collection are summarized in Table 1 and examples are shown in Figure 1A and B. The top panel of Figure 1A shows some of the 611-bp products from the peanut samples. The band in lane 2 represents 1 seed positive for PStV of 100 in the composite sample (verified by ELISA). Lanes 4 and 5 in the bottom panel represent the 339-bp product produced with a 100 -seed sample containing 1 seed positive for PeMV (as determined by ELISA). The band produced in Figure 1A, lane 4 is very faint. A 339-bp product is formed with the PeMV-infected lines (Fig. 1A, bottom panel, and 1B). Only 3 of 106 peanut seed lots grown in Ecuador were infected with virus (PeMV; Fig. 1B, lanes 3 and 4) and none were infected with PStV. In order to ascertain the virus-free seed in the three contaminated lots, ELISA testing was conducted. ELISA testing of randomly selected seed lots confirmed the IC-RTPCR results (Table 1).

A number of potential problems can be avoided when using the IC-RT-PCR method. (i) Lots of PCR tubes vary in their properties for binding serum proteins. Therefore, tube lots should be tested before use for large numbers of samples. (ii) Tubes should be washed with freshly made solutions and the washed tubes should be used within 1 month for best results. (iii) Seed and leaf extracts are best if used when fresh. Extracts kept until the next day at $4^{\circ} \mathrm{C}$ produce results, but not all bands seen on the first day will be produced. (iv) Introducing the PBST into the tubes using a wash bottle instead of a micropipette and then removing the liquid by slinging it out into a sink was faster, but also produced inconsistent results. Water pressure from the wash bottle or the shaking of the liquid from the tubes probably dislodges the virus 


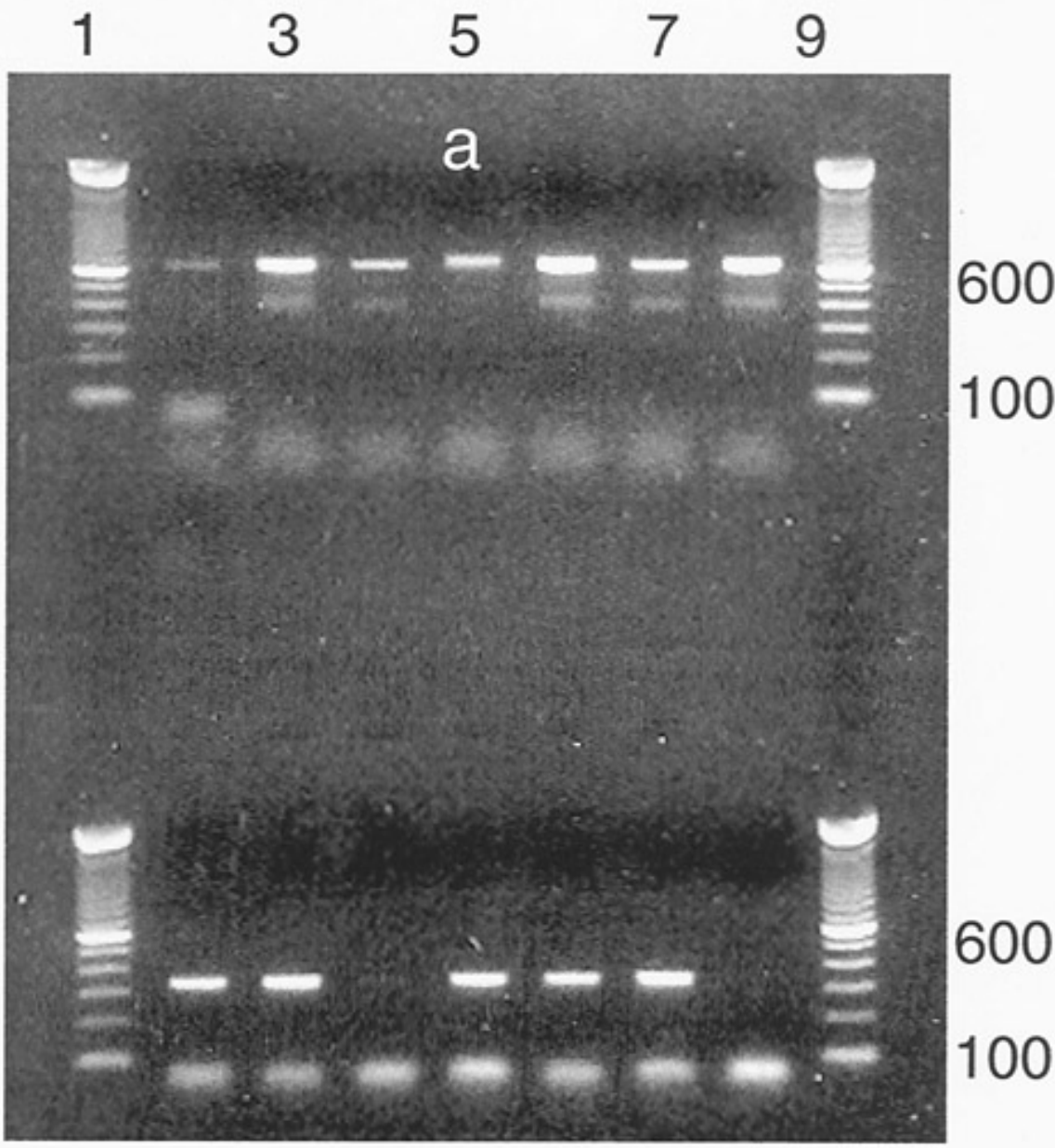

$\begin{array}{lllllllllllll}1 & 3 & 5 & 7 & 9 & 11 & 13 & 15 & 17 & 19 & 21 & 23 & 25\end{array}$

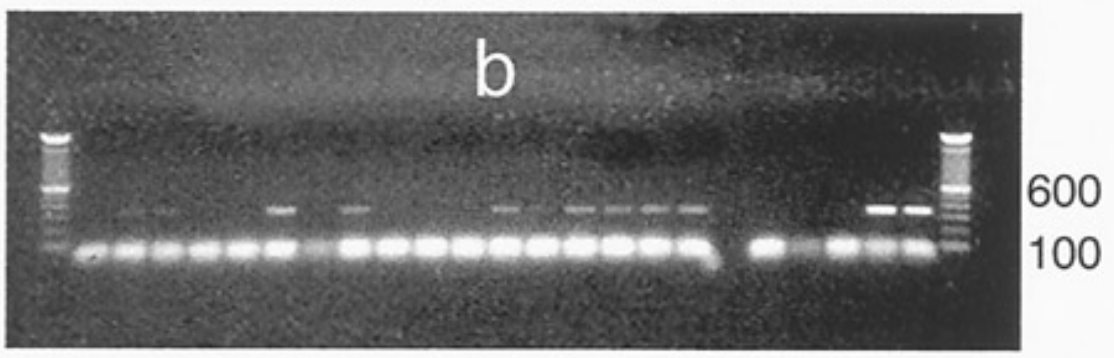

Fig. 1. (A) Immunocapture-reverse transcription-polymerase chain reaction (IC-RT-PCR) bands with antiserum to Peanut strip virus (PStV; top row) and Peanut mottle virus (PeMV; bottom row). Lanes 2 to 8 contain extracts from seeds of Plant Introduction numbers (PIs) 118989, 274194, 274197, 275687, 442581, 442588, and 442589, respectively. Lanes 1 and 9 contain a 100-base-pair (bp) ladder marker. (B) IC-RT-PCR bands of peanut seed extracts for PeMV. Lanes 2 to $6=$ Ecuadorian peanuts Grifs $12515,12578,12595,12596,12598$, respectively; lanes 7 to $18=$ PIs 118989,274194 , 274197, 275687, 275688, 468134, 442708, 442589, 442588, 442581, 429449, and 429444; and lanes 20 to $22=$ PIs 306232, 275695, and 475976, respectively. Lanes 23 and $24=$ PeMV-infected leaf and seed controls, respectively. Lanes 1 and 25 contain a 100-bp ladder marker; lane 19 is blank.

from the tube walls. (v) Seed slices can be ground in a mortar with a pestle but, to be certain of even processing of all seed pieces, the grinding-bag approach is better. To produce the most homogeneous slurry from the 100 seed slices, it is best to grind half of the slices with $5 \mathrm{ml}$ of buffer, save the slurry, rinse the bag with an additional $5 \mathrm{ml}$ of buffer, then repeat for the second half of the seed slices and combine the two slurries. (vi) The RT-PCR procedure can be split, treating the tubes with $20 \mu \mathrm{l}$ of the
RT mix, then processing the samples in the thermocycler at $37^{\circ} \mathrm{C}$ for $2 \mathrm{~h}$ and $94^{\circ} \mathrm{C}$ for $2 \mathrm{~min}$, and then following with $30 \mu \mathrm{l}$ of the PCR mix to complete the process. However, some time is saved by placing everything into the tube and then processing the sample through the entire series. This second approach may be slightly more sensitive because the entire area is exposed to the $50 \mu \mathrm{l}$ of test sample. (vii) Samples should be replicated for each antiserum to eliminate inconsistent results (i.e., some tubes may not have bands). We do not know whether the inconsistent results are due to the antiserum-virus complex accidentally being removed from the tube or whether it did not attach in the first place.

The IC-RT-PCR procedure allows for a large number of seed lots to be tested in a given time period and is an important step toward improving virus detection for germ plasm handling and distribution.

\section{LITERATURE CITED}

1. Adams, A. N., Guise, C. M., and Crossley, S. J. 1999. Plum pox virus detection in dormant plum trees by PCR and ELISA. Plant Pathol. 48:240-244.

2. Cassidy, B., Sherwood, J. L., and Nelson, R. S. 1993. Cloning of the capsid protein gene from a blotch isolate of peanut stripe virus. Arch. Virol. 128:287-297.

3. Demski, J. W., and Lovell, G. R. 1985. Peanut stripe virus and the distribution of peanut seed. Plant Dis. 69:734-738.

4. Demski, J. W., Reddy, D. V. R., Sowell, G., Jr., and Bays, D. 1984. Peanut stripe virus-a new seedborne potyvirus from China infecting groundnut (Arachis hypogaea). Ann. Appl. Biol. 105:495-501.

5. Demski, J. W., and Warwick, D. 1986. Direct test of peanut seed for the detection of peanut stripe virus. Peanut Sci. 13:38-40.

6. Flasinsk, S., Gonzales, R. A., and Cassidy, B. G. 1997. The complete nucleotide sequence of peanut mottle virus (strain M). Genbank Locus AF023848.

7. Jelkmann, W., and Keim-Konrad, R. 1997. Immunocapture polymerase chain reaction and plate-trapped ELISA for the detection of Apple stem pitting virus. Phytopathol. Z. 145:499-503.

8. Kuhn, C. W. 1965. Symptomatology, host range, and effect on yield of a seed-transmitted peanut virus. Phytopathology 55:880-884.

9. Lynch, R. E., Demski, J. W., Branch, W. D. Holbrook, C. C., and Morgan, L. W. 1988. Influence of Peanut stripe virus on growth yield, and quality of florunner peanut. Peanut Sci. 15:47-52.

10. MacKenzie, D. J., McLean, M. A., Mukerji, S., and Green, M. 1997. Improved RNA extraction from woody plants for the detection of viral pathogens by reverse transcriptionpolymerase chain reaction. Plant Dis. 81:222226.

11. Nolasco, G., De Blas, C., Torres, V., and Ponz, F. 1993. A method combining immunocapture and PCR amplification in a microtiter plate for the detection of plant viruses and subviral pathogens. J. Virol. Methods 45:201218.

12. Pasquini, G., Simeone, A. M., Conte, L., and Barba, M. 1998. Detection of plum pox virus in apricot seeds. Acta Virol. (Engl. Ed.) 42:260-263.

13. Pinnow, D. L., Chalkley, J. H., and Demski, J. W. 1990. A practical method for the detection of peanut stripe virus in peanut seed. Ga. Agric. Exp. Stn. Res. Rep. 584.

14. Sherwood, J. L., Pennington, R. E., Cassidy, B. G., and Nelson, R. S. 1992. Detection of Peanut stripe virus in peanut seed using the po RNasin RNase inhibitor (Promega Corp., Madison, WI) lymerase chain reaction. (Abstr.) Proc. Am. Peanut Res. Edu. Soc. 24:39.

15. Werner, R., Muhlbach, H. P., and Buttner, C. 1997. Detection of Cherry leaf roll nepovirus (CLRV) in birch, beech, and petunia by immunocapture RT-PCR using a conserved primer pair. Eur. J. For. Pathol. 27:309-318. 